\title{
Pengaruh Kecukupan Modal dan Risiko Kredit Terhadap Likuiditas Pada Bank Umum Syariah Yang Terdaftar di Bank Indonesia
}

\author{
Budhi Pamungkas G', Rizka Annisa ${ }^{2}$, Ikaputera Waspada ${ }^{3}$
}

Program Studi Manajemen, FPEB, Universitas Pendidikan Indonesia, Bandung, Indonesia ${ }^{1}$ Program Studi Manajemen, FPEB, Universitas Pendidikan Indonesia, Bandung, Indonesia ${ }^{2}$ Program Studi Pendidikan Ekonomi, FPEB, Universitas Pendidikan Indonesia, Bandung, Indonesia ${ }^{1}$

\begin{abstract}
This research is based on the increasing number of liquidity of Islamic General Bank which is registered in Bank of Indonesia. The aim of this research is to find out the image of capital adequacy by using CAR indicator, credit risk by using NPF indicator and examine the impact of capital adequacy and credit risk towards the liquidity of islamic general bank which is registered in Bank of Indonesia. The research method used in this research is descriptive and verification method. This research used capital adequacy secondary data, credit risk and liquidity which are based on the financial statements from each bank which have been managed in 2012-2016 period. The analysis technique for this research was by using classical assumption test, regression analysis panel data and hypothesis test. This study used purposive sampling in islamic general bank registered in Bank of Indonesia in 2012-2016 period. This research was done by panel data analysis that was assisted by an application named Eview 8. Based on regression significance test, the capital adequacy and credit risk have influenced the liquidity itself. Based on the regression coefficient test, the capital adequacy gave significant positive effect to the liquidity, while the credit risk gave significant negative effect to liquidity.
\end{abstract}

Keywords. capital adequacy; credit risk; liquidity

Abstrak

Penelitian ini dilatarbelakangi oleh meningkatnya likuiditas pada Bank Umum Syariah yang terdaftar di Bank Indonesia. Tujuan dari penelitian ini adalah untuk mengetahui gambaran kecukupan modal dengan menggunakan indikator CAR, risiko kredit dengan menggunakan indikator NPF dan likuiditas dengan menggunakan indikator FDR serta menguji pengaruh kecukupan modal dan risiko kredit terhadap likuiditas pada bank umum syariah yang terdaftar di Bank Indonesia. Metode penelitian yang dilakukan dalam penelitian ini yaitu dengan menggunakan metode deskriptif dan verifikatif. Data yang digunakan dalam penelitian ini adalah data sekunder kecukupan modal, risiko kredit dan likuiditas yang bersumber dari laporan keuangan dari masing-masing bank yang sudah diolah periode 2012-2016. Teknik analisis yang dilakukan dalam penelitian ini dengan menggunakan uji asumsi klasik, analisis regresi data panel dan uji hipotesis. Penelitian ini menggunakan teknik penelitian dengan cara purposive samplingpada bank umum syariah yang terdaftar di Bank Indonesia periode 2012-2016. Penelitian ini dilakukan menggunakan analisis data paneldengan dibantu oleh aplikasi Eviews 8. Berdasarkan uji keberartian regresi, kecukupan modal dan risiko kredit berpengaruh terhadap likuiditas. Berdasarkan uji koefisien regresi, kecukupan modal berpengaruh positif signifikan terhadap likuiditas, sedangkan risiko kredit berpengaruh negatif signifikan terhadap likuiditas.

Kata kunci. kecukupan modal; risiko kredit; likuiditas

Corresponding author. Email. budhipamungkas@upi.edu ${ }^{1}$ arizkachika05@gmail.com², ikaputerawaspada@upi.edu ${ }^{3}$

How to cite this article. Budhi, P. G., Annisa, R., \& Waspada, I. (2018). Pengaruh Kecukupan Modal dan Risiko Kredit Terhadap Likuiditas Pada Bank Umum Syariah Yang Terdaftar di Bank Indonesia. Jurnal Pendidikan $\begin{array}{lllll}\text { Akuntansi Dan Keuangan, } & 6(2), & 77-86 . & \text { Retrieved }\end{array}$ http://ejournal.upi.edu/index.php/JPAK/article/view/15908

History of article. Received: Februari 2018, Revision: Mei 2018, Published: Juli 2018

\section{PENDAHULUAN}

Bank adalah usaha yang berbentuk lembaga keuangan yang menghimpun dana dari masyarakat yang memiliki kelebihan dana (surplus of fund) dan menyalurkannya kembali kepada masyarakat yang kekurangan dana (lack of fund), serta memberikan jasa-jasa bank lainnya untuk motif profit juga sosial demi meningkatkan taraf hidup rakyat banyak. Berdasarkan prinsipnya Bank dibagi menjadi 2 yaitu, bank konvensional dan bank dengan menggunakan prinsip syariah. Pada UU no.
21 tahun 2008 tentang perbankan syariah disebutkan bahwa Bank Syariah adalah Bank yang menjalankan kegiatan usahanya berdasarkan Prinsip Syariah. Dalam UU no 10 tahun 1998 memberi arahan bagi bankbank konvensional untuk membuka cabang syariah/ unit usaha syariah (UUS) atau mengkonversi menjadi bank syariah. Menurut jenisnya Bank Syariah terdiri atas Bank Umum Syariah (BUS) dan Bank Pembiayaan Rakyat Syariah (BPRS).

Bank Indonesia selaku regulator dari perbankan di Indonesia sangat mendukung 
berkembangnya perbankan syariah, karena secara makro perkembangan Bank Syariah dapat meberikan daya dukung terciptanya stabilitas sistem keuangan dan perekonomian nasional (www.kompasiana.com). Akhir 2016, pertumbuhan perbankan syariah terlihat sedikit melambat. Pada kuartal IV/2016 jumlah pertumbuhan bank syariah berada di bawah industri perbankan dan juga bank nasional yakni $\quad 7,21 \%$ (www.ekbis.sindonews.com).

Mengembangkan perbankan syariah salah satunya dengan melihat kepada aspek penilaian tingkat kesehatan bank di Indonesia yang sampai saat ini secara garis besar didasarkan pada faktor CAMEL (Capital, Assets Quality, Management, Earning dan Liquidity). Apabila suatu bank mengalami permasalahan pada salah satu faktor tersebut, maka bank tersebut akan mengalami kesulitan.

Pada penelitian yang dilakukan oleh Harjum Muharam (2013) faktor yang mempengaruhi likuiditas salah satunnya adalah CAR, yang menyatakan bahwa CAR berpengaruh negatif terhadap likuiditas. Berdasarkan penelitian yang dilakukan oleh Prihatiningsih (2011) dan Anindya (2016) yang mengatakan salah satu faktor yang dapat mempengaruhi likuiditas adalah CAR menyatakan bahwa CAR berpengaruh positif terhadap likuiditas. Selain itu juga terdapat faktor-faktor lain yang bertentangan antar penelitian yang sudah dilakukan. Dengan adanya gap penelitian tersebut maka perlu diteliti ulang mengenai likuiditas pada bank umum syariah.

Likuiditas perbankan syariah mengalami penurunan, Gejala ini tercermin dari financing to deposit ratio (FDR) bank umum syariah sebesar $82,69 \%$ per Juni 2017 atau turun dari $89,32 \%$ di posisi Juni tahun 2016 (www.keuangan.kontan.co.id). Tetapi pada akhir tahun 2016 FDR di Bank Umum Syariah mencapai 94,54\%. Sebagai perbandingan, LDR industri perbankan pada 2016 tercatat $91,71 \%$. Sementara LDR bank kakap atau BUKU IV sebesar 86,61\%. Disusul LDR BUKU I dan II masingmasing sebesar $81,59 \%$ dan $92,49 \%$ (www.keuangan.kontan.co.id), dari berita tersebut maka dapat disimpulkan bahwa FDR perbankan syariah tinggi, hal ini tentu saja dapat berdampak buruk apabila tidak ditangani dengan tepat, dan membuat FDR bank syariah menjadi semakin mengalami peningkatan.Selain itu menurut penelitian Akhtar et al (2011) menunjukkan bahwa manajemen risiko likuiditas bank konvensional lebih baik jika dibandingkan dengan bank syariah. Oleh karena itu manajemen likuiditas pada bank syariah haruslah diperhatikan agar likuiditas bank syariah dapat terjaga dengan stabil, dengan cara mengatur keluar masuknya dana.

Dari gap penelitian tersebut, maka penting untuk mencari faktor-faktor apa saja yang dapat mempengaruhi likuiditas. Menurut Munawir (2002) faktor yang mempengaruhi tingkat likuiditas, diantaranya Modal kerja, dapat menimbulkan perusahaan illikuid. Terlalu besar kewajiban jangka pendek/kewajiban lancar bila dibandingkan dengan modal kerja, juga akan menyebabkan perusahaan dalam keadaan illikuid. Dan ada pula beberapa hal yang dapat mempengaruhi liquidity dan intermediasi perbankan. Pada penelitian yang dilakukan oleh Berger (2006), menyebutkan bahwa pengaruh tersebut dapat berasal dari banyak hal seperti risiko dari aktifitas bank tersebut (bank risk), dan ukuran bank tersebut (capital).

Faktor pertama dalam mempengaruhi Likuiditas adalah Kecukupan Modal. Kecukupan modal adalah suatu regulasi perbankan yang menetapkan suatu kerangka kerja mengenai bagaimana bank dan lembaga penyimpanan harus menangani permodalan mereka. Kecukupan modal bank yang dinyatakan dengan suatu rasio tertentu yang disebut rasio kecukupan modal atau capital adequacy ratio (CAR). CAR merupakan indikator terhadap kemampuan bank untuk menutupi penurunan aktivanya sebagai akibat dari kerugian-kerugian bank yang disebabkan oleh aktiva yang berisiko (Dendawijaya, 2009). Bank Indonesia mensyaratkan minimal sebuah bank mempertahankan CAR-nya $8 \%$.

Semakin tinggi CAR maka likuiditas bank juga akan semakin tinggi karena fungsi intermediasi dapat dilaksanakan dengan optimal jika didukung oleh permodalan yang memadai (Buchory, 2004). Bank yang memiliki CAR tinggi maka kredit yang disalurkan cenderung tinggi yang dibantu pasar uang dengan melakukan hutang dalam bentuk setrtifikat BI selain itu juga bank mencadangkan sebagian dananya untuk melakukan kewajibannya kepada DPK apabila deposan mengambil kembali dananya. Sehingga apabila CAR meningkat maka akan meningkatkan likuiditas.

Namun sebaliknya menurut Ali (2004). Capital Adequancy Ratio (CAR) merupakan rasio permodalan yang menunjukan kemampuan bank dalam menyediakan dana 
yang diakibatkan oleh kegiatan operasi bank tersebut, semakin tinggi CAR maka semakin besar pula sumber daya finansial yang dapat digunakan untuk keperluan pengembangan usahanya dan mengantisipasi potensi kerugian yang diakibatkan oleh penyaluran kredit, sehingga likuiditas bank akan mengalami penurunan.

Faktor kedua yang mempengaruhi likuiditas adalah kualitas aset. Kualitas Aset atau aktiva produktif bank syariah adalah penanaman dana bank baik dalam rupiah maupun valuta asing dalam bentuk pembiayaan, piutang, qordh, surat beharga, penyertaan modal, komitmen, dan kontijensi pada rekening administratif serta sertifikat wadiah bank itu sendiri yang dijelaskan dalam PBI No 5/7PBI/ 2003. Salah satu alat ukur indikator kualitas aset dengan melihat rasio Non Performing Financing (NPF). Mahsyud Ali (2006), mengatakan bahwa Non Performing Financing (NPF) adalah risiko kerugian yang diderita bank, terkait dengan kemungkinan bahwa pada saat jatuh tempo debiturnya/pengguna dana gagal memenuhi kewajibannya terhadap bank.

Semakin kecil rasio NPF akan semakin baik tingkat kesehatan suatu bank karena minimnya kredit/pembiayaan yang gagal bayar, dimana gagal bayar pada suatu bank merupakan sinyal negatif bagi bank dan akan mempengaruhi tingkat likuiditas yang diukur dengan indikator menurunnya tingkat FDR (Leon dan Ericson, 2007). Sehingga hubungan NPF dengan likuiditas adalah semakin kecil risiko kredit maka likuiditas akan semakin besar. Hal tersebut dikarenakan dana yang dipakai untuk penyaluran pembiayaan sebagian besar berasal dari dana DPK yang tentu saja akan ditarik sewaktu-waktu, dan bank harus mampu memenuhi permintaan penarikan dana oleh DPK. NPF bank syariah merupakan rasio antara total pembiayaan yang bermasalah dengan total pembiayaan yang disalurkan. Jadi, semakin tinggi persentase rasio NPF mengindikasikan semakin buruk kualitas pembiayaan yang disalurkan yang pada akhirnya akan berpengaruh terhadap penurunan kinerja fungsi intermediasi bank yang bersangkutan karena bank akan semakin ketat dalam penyaluran pembiayaan mengingat bank harus melakukan recovery dana atas dana yang tidak kembali dari pembiayaan yang gagal bayar.Sedangkan Menurut Ismal (2011) kenaikan NPF akan mempengaruhi kemungkinan terjadinya permasalahan permasalahan dalam risiko likuiditas, peningkatan NPF dapat menurunkan peningkatan pembiayaan sehingga berpeluang bank Syariah mengalami permasalahan likuiditas, dengan dilihat pada indikator meningkatnya tingkat FDR bank Syariah.

Dari fenomena-fenomena tersebut, maka penulis akan menganalisi lagi fartorfaktor apa saja yang mempengaruhi likuiditas pada Bank Umum Syariah yang diukur dengan rasio FDR dengan menggunakan indikator kecukupan modal dan risiko kredit. Dengan itu penulis membuat penelitian dengan mengambil judul "Pengaruh Kecukupan Modal dan Risiko Kredit Terhadap Likuiditas Pada Bank Umum Syariah yang Terdaftar di Bank Indonesia".

Rumusan Masalah dalam penelitian ini yaitu (1) Bagaimana gambaran tingkat Kecukupan Modal Bank Umum Syariah yang terdaftar di Bank Indonesia pada periode 2012-2016? (2) Bagaimana gambaran tingkat Risiko Kredit Bank Umum Syariah yang terdaftar di Bank Indonesia pada periode 2012-2016? (3) Bagaimana gambaran tingkat Likuiditas Bank Umum Syariah yang terdaftar di Bank Indonesia pada periode 2012-2016? (4) Bagaimana pengaruh dari Kecukupan Modal terhadap Likuiditas pada Bank Umum Syariah yang terdaftar di Bank Indonesia pada periode 2012-2016? (5) Bagaimana pengaruh dari Risiko Kredit terhadap Likuiditas pada Bank Umum Syariah yang terdaftar di Bank Indonesia pada periode 2012-2016?

\section{KAJIAN PUSTAKA \\ Likuiditas}

Likuiditas (Y) dihitung dengan indikator Financing to Deposit Ratio (FDR). FDR menunjukkan seberapa jauh kemampuan bank dalam membayar kembali penarikan dana yang dilakukan deposan dengan mengandalkan kredit yang diberikan sebagai sumber likuiditasnya (Dendawijaya, 2009). Besarnya FDR menurut peraturan pemerintah Bank Indonesia maksimum adalah $110 \%$.

\section{Kecukupan Modal}

Kecukupan Modal (X1) dihitung dengan indikator capital adequacy ratio (CAR). CAR adalah rasio kinerja bank untuk mengukur kecukupan modal yang dimiliki bank untuk menunjang aktiva yang mengandung atau menghasilkan risiko, misalnya kredit yang diberikan. Bank Indonesia mensyaratkan minimal CAR sebuah bank yaitu berada diantara 10\% $14 \%$.

\section{Risiko Kredit}


Risiko Kredit (X2) dihitung dengan menggunakan indikator Non Performing Financing (NPF). NPF adalah risiko kerugian yang diderita bank, terkait dengan kemungkinan bahwa pada saat jatuh tempo debeturnya/pengguna dana gagal memenuhi kewajibannya terhadap bank. Berdasarkan ketetapan Bank Indonesia NPF diusahakan dalam tingkat yang wajar berkisar antara $3 \%-5 \%$ dari total kreditnya.

\section{METODE PENELITIAN}

Objek dan Subjek Penelitian

Objek yang akan dianalisis adalah Kecukupan Modal yang diukur dengan menggunakan rasio Capital Adequancy Ratio (X1) merupakan variabel independen, Kualitas Aset yang diukur dengan menggunakan rasio Non Performing Financing (X2) merupakan variabel independen, dan Likuiditas yang diukur dengan Financing to Deposit Ratio (FDR) merupakan variabel dependen.

Subjek dalam penelitian ini adalah Bank Umum Syariah yang terdaftar di Bank Indonesia.

\section{Metode Penelitian}

Metode yang digunakan adalah metode deskriptif dan metode verifikatif. Metode ini digunakan untuk mengetahui gambaran Kecukupan Modal, Kualitas Asset dan Likuiditas pada Bank Umum Syariah yang terdaftar di Bank Indonesia. Metode verifikatif digunakan untuk mengetahui pengaruh dan menguji sebab akibat Kecukupan Modal dan Kualitas Aset terhadap Likuiditas pada Bank Umum Syariah yang terdaftar di Bank Indonesia.

\section{Desain Penelitian}

Desain penelitian dalam penelitian ini menggunakan desain kausal, karena penelitian ini bertujuan mencari pengaruh atau hubungan sebab akibat antara indikator Kecukupan Modal yang diukur dengan rasio (Capital Adequency Ratio) CAR dan Kualitas Aset yang diukur dengan rasio (Non Performing Financing) NPF terhadap likuiditas yang diukur dengan rasio (Financing to Deposit Ratio) FDR.

\section{Teknik Pengumpulan Data}

Dalam penelitian ini teknik yang digunakan dalam pengumpulan data dengan menggunakan studi dokumentasi. Teknik tersebut merupakan teknik pengumpulan data dengan mengambil data dari masingmasing laporan keuangan setiap Bank Umum Syariah yang terdaftar di Bank Indonesia pada tahun 2012 - 2016.

\section{Populasi dan Sampel}

Populasi dalam penelitian ini adalah laporan-laporan keuangan tahun 2012-2016 pada 11 Bank Umum Syariah yang terdaftar di Bank Indonesia.

. Sampel pada penelitian ini adalah data kecukupan modal dengan rasio CAR, data kualitas aset dengan rasio NPF, dan data likuiditas dengan rasio FDR yang terdapat pada laporan keuangan tahun 2012-2016 dengan melakukan penelitian pada 11 Bank Umum Syariah yang terdaftar di Bank Indonesia.

\section{Operasional Variabel}

- Kecukupan Modal (X1) diukur dengan menggunakan indikator Capital Adequancy Ratio (CAR) dengan rumus:

$$
\mathrm{CAR}=\frac{\text { Modal sendiri }}{\text { ATMR }} \times 100 \%
$$

- Risiko Kredit (X2) diukur dengan menggunakan indikator Non Performing financing (NPF) dengan rumus $\mathrm{NPF}=\frac{\text { Pembiayaan Bermasalah }}{\text { Total Pembiayaan }} \times 100 \%$

- Likuiditas (Y) diukur dengan menggunakan indikator Financing to Deposit Ratio (FDR) dengan rumus

$$
\text { FDR }=\frac{\text { Total Pembiayaan }}{\text { DPK }+ \text { Modal Sendiri }} \times 100 \%
$$$$
\text { Uji Hipotesis }
$$

- Uji Keberartian Regresi (Uji F)

1. $F_{\text {hitung }}>F_{\text {tabel }}$ atau nilai sig $<$ taraf signifikansi 0,05 atau $5 \%$ maka $\mathrm{H}_{0}$ ditolak dan $\mathrm{H}_{\mathrm{a}}$ diterima (Regresi berarti)

2. Fhitung $<$ Ftabel atau nilai sig $>$ taraf signifikansi 0,05 atau $5 \%$ maka $\mathrm{H} 0$ diterima dan Ha ditolak (regresi tidak berarti)

Jika uji $\mathrm{F}$ menunjukan regresi berarti, maka dapat dilanjutkan dengan uji t.

\section{- Uji Koefisien Regresi (Uji T)}

1. Menentukan Hipotesis

\section{Hipotesis 1 :}

Ho : $\beta_{1}=0$ variabel kecukupan modal tidak berpengaruh terhadap likuiditas.

Ho : $\beta_{1} \neq 0$ variabel kecukupan modal berpengaruh terhadap likuiditas.

Hipotesis 1 :

Ho : $\beta_{2}=0$ variabel risiko kredit tidak berpengaruh terhadap likuiditas.

Ho : $\beta_{2}<0$ variabel risiko kredit berpengaruh negatif terhadap likuiditas.

2. Level of significant $\alpha=0,05$

3. Kriteria Pengujian

Ho : diterima apabila $-t_{\text {tabel }} \leq t_{\text {hitung }} \leq$ $t_{\text {tabel }}$

Ho : ditolak apabila $t_{\text {hitung }}>t_{\text {tabel }}$ atau $t_{\text {hitung }}<t_{\text {tabel }}$

\section{Rancangan Analisis Data}


Langkah-langkah analisis yang diperlukan dalam penelitian ini adalah sebagai berikut:

1. Mengumpulkan data yang dibutuhkan dalam penelitian mengenai gambaran Kecukupan Modal, Risiko Kredit dan Likuiditas Bank Umum Syariah.

2. Menyusun kembali data yang telah diperoleh kedalam bentuk table maupun grafik

3. Analisis gambaran terhadap Kecukupan Modal yang diukur dengan Capital Adequacy Ratio (CAR).

4. Analisis gambaran terhadap Risiko Kredit yang diukur dengan Non Performing Financing (NPF).

5. Analisis gambaran likuiditas yang diukur dengan Financing to Deposit Ratio (FDR).

6. Melakukan analisis statistic untuk mengetahui pengaruh Kecukupan Modal terhadap Likuiditas.

7. Meakukan analisis statistic untuk mengetahui pengaruh Risiko Kredit terhadap Likuiditas.

\section{HASIL PENELITIAN}

Gambaran Kecukupan Modal yang Diukur dengan Indikator Capital Adequancy Ratio (CAR)



Sumber: Laporan keuangan masing-masing bank (data diolah)

Gambar 1. Perkembangan kecukupan modal pada bank umum syariah

Perkembangan rata-rata kecukupan modal yang diukur dengan rasio CAR. Selama periode 2012 - 2016 nilai CAR Bank Umum Syariah mengalami perkembangan yang fluktuatif cenderung meningkat. Rata - rata CAR Bank Umum Syariah tertinggi terjadi pada tahun 2016 yaitu sebesar $22,72 \%$.

Gambaran Risiko Kredit yang Diukur dengan Indikator Non Performing Financing (NPF)

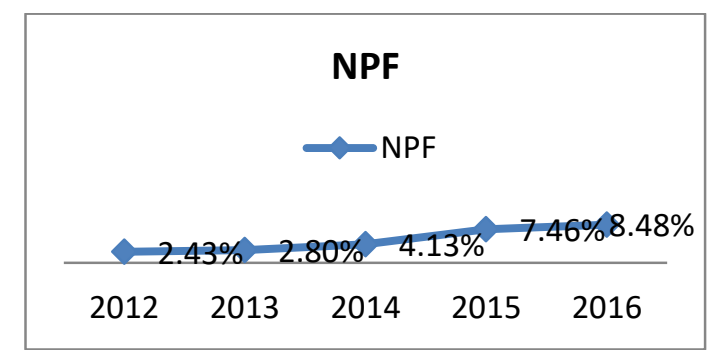

Sumber: Laporan keuangan masing-masing bank (data diolah)

Gambar 3. Perkembangan risiko kredit pada bank umum syariah

Selama tahun $2012 \quad-\quad 2016$ perkembangan rata - rata nilai NPF Bank Umum Syariah mengalami peningkatan dari tahun ke tahun. Rata - rata NPF Bank Umum Syariah tertinggi terjadi pada tahun 2016 yaitu sebesar $8,48 \%$.

\section{Gambaran Likuiditas yang Diukur dengan Indikator Financing to Deposit Ratio (FDR)}

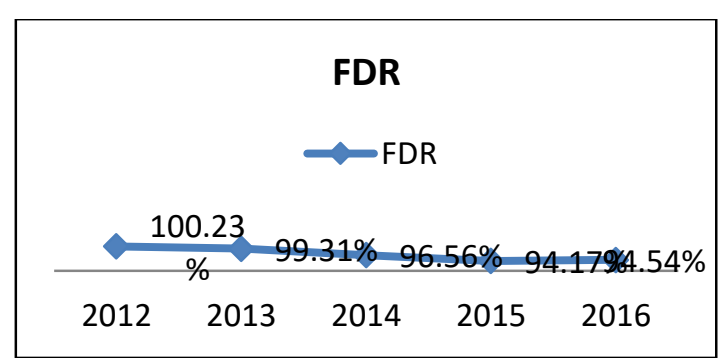

Sumber: Laporan keuangan masing-masing bank (data diolah)

Gambar 2. Perkembangan likuiditas pada bank umum syariah

Selama periode 2012-2016 perkembangan rata - rata nilai likuiditas yang diukur dengan indikator Financing to Deposit Ratio (FDR) Bank Umum Syariah mengalami perkembangan yang fluktuatif cenderung menurun, namun pada tahun terakhir yaitu tahun 2016 FDR Bank Umum Syariah mengalami kenaikan. Rata - rata dari nilai FDR Bank Umum Syariah meningkat pada tahun 2016 yaitu sebesar $94,54 \%$.

Analisis Hasil Statistika

Tabel 1. Statistik Deskriptif

\begin{tabular}{cccc}
\hline & LOG FDR & CAR & NPF \\
\hline Mean & 4.558202 & 21.28709 & 5.060364 \\
Median & 4.531416 & 17.81000 & 3.260000 \\
Maximum & 5.286751 & 63.89000 & 43.99000 \\
Minimum & 4.301088 & 11.10000 & 0.100000 \\
Std. Dev. & 0.169091 & 12.16375 & 7.389726 \\
Observations & 55 & 55 & 55 \\
\hline Sumber: Output Eviews 8 & &
\end{tabular}




\section{Pengujian Asumsi Klasik}

\section{Uji Normalitas}

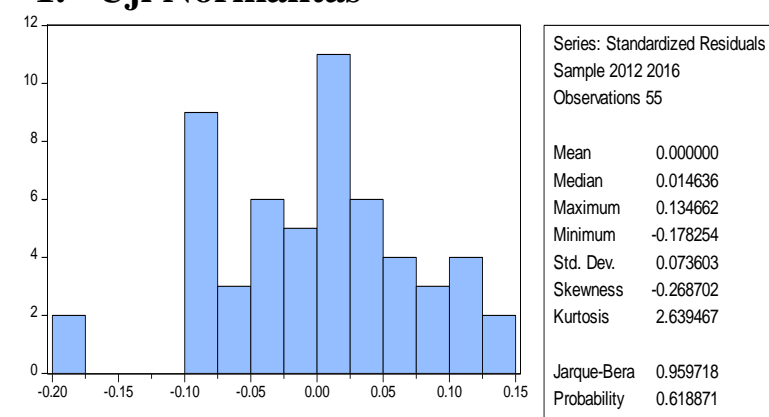

Sumber: Output Eviews 8

Nilai probabilitas sebesar 0,618871 yaitu lebih besar dari 5\%, maka dapat disimpulkan bahwa data berdistribusi normal.

Tabel 2. Uji Multikolinearitas

\begin{tabular}{cccc}
\hline & LOG FDR & CAR & NPF \\
\hline LOG FDR & 1 & 0.779872 & 0.280206 \\
CAR & 0.779872 & 1 & 0.305586 \\
NPF & 0.280206 & 0.305586 & 1 \\
\hline
\end{tabular}

Sumber: Output Eviews 8

Nilai koefisien korelasi antar variabel independen CAR kurang dari 0,8, sehingga bisa diasumsikan bahwa antar independent variable tidak terjadi masalah multikoleniaritas.

Tabel 4. Uji Autokorelasi

\begin{tabular}{|c|c|}
\hline Mean dependent var & 4.558202 \\
\hline S.D. dependent var & 0.169091 \\
\hline Sum squared resid & 0.292540 \\
\hline Durbin-Watson stat & 1.477256 \\
\hline
\end{tabular}

Sumber: Output Eviews 8

Nilai DW sebesar 1,477256, hal ini menunjukkan nilai DW berada diantara -2 sampai dengan 2, maka dapat disimpulkan bahwa di dalam persamaan regresi tidak terjadi masalah autokorelasi.

\section{Uji Heterokedastisitas}

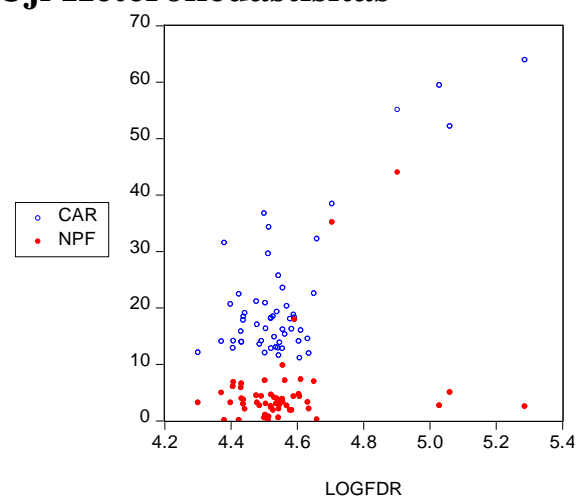

Sumber: Output Eviews 8

$$
\text { LOGFDR }
$$

Sebaran titik - titik pada grafik plot tidak menunjukan adanya pola tertentu, maka dapat disimpulkan bahwa model regresi tidak terjadi heterokedastisitas.

\section{Pemilihan Model Analisis Regresi Data} Panel

Pada Uji Chaw Nilai probabilitas (Prob.) lebih kecil dari 0,05 maka digunakan metode Fixed Effect. Selanjutnya dilakukan uji Hausman, dan menghasilkan nilai probabilitas (Prob.) lebih kecil dari 0,05 maka tetap model yang digunakan adalah model Fixed Effect

Tabel 3. Analisis Regresi

\begin{tabular}{ccccc}
\hline Variable & Coefficient & Std. Error & t-Statistic & Prob. \\
\hline C & 4.404856 & 0.072136 & 61.06300 & 0.0000 \\
CAR & 0.008300 & 0.003127 & 2.653863 & 0.0112 \\
NPF & -0.004612 & 0.002103 & -2.192920 & 0.0339 \\
\hline
\end{tabular}

FDR $=4.404+0.008 C A R-0.004 N P F$

Dari model regresi tersebut dapat dijelaskan bahwa :

1. Nilai konstanta (a) sebesar 4,404. Artinya jika nilai kecukupan modal dan risiko kredit bernilai 0 atau konstan, maka likuiditas mengalami peningkatan sebesar $4.404 \%$.

2. Nilai koefisien regresi kecukupan modal $\left(\mathrm{X}_{1}\right)$ sebesar 0,008 . Artinya jika kecukupan modal bertambah $1 \%$, maka likuiditas akan mengalami peningkatan sebesar 0,008\% (dengan asumsi seemua variabel lainnya konstan)

3. Nilai koefisien regresi risiko kredit $\left(\mathrm{X}_{2}\right)$ sebesar 0,004. Artinya jika risiko kredit bertambah $1 \%$, maka likuiditas akan mengalami penurunan sebesar $0,004 \%$ (dengan asumsi seemua variabel lainnya konstan).

\section{Uji Hipotesis}

Tabel 5. Uji f

R-squared $\quad 0.810527$ Mean dependent var 4.558202

\begin{tabular}{llll}
\hline Adjusted R-squared 0.756391 & S.D. dependent var 0.169091
\end{tabular}

S.E. of regression 0.083458 Sum squared resid 0.292540

F-statistic $\quad 14.97226$ Durbin-Watson stat 1.477256

Prob(F-statistic) $\quad 0.000000$

Sumber: Output Eviews 8

Fhitung sebesar 14,97226 dan nilai probabilitas (signifikansi) sebesar 0,000000. Sedangkan $\mathrm{F}_{\text {tabel }}$ yang didapat dengan cara menghitung dengan derajat kepercayaan $5 \%$, jumlah sampel $\mathrm{N}=55$ dan jumlah variabel independen $\mathrm{K}=3$, maka $\mathrm{F}_{((\mathrm{k}-1) \text {; }(\mathrm{N}-\mathrm{K}))}$ $=\mathrm{F}_{(2: 52)}$ dilihat pada tabel uji $\mathrm{F}$, diperoleh nilai $\mathrm{F}$ tabel sebesar 3,18 . Sehingga nilai $F_{\text {hitung }}(14,97226)>F_{\text {tabel }}(3,18)$. Sedangkan untuk nilai signifikansi $(0,000000)<0,05$. Maka dapat diartikan bahwa model regresi pada uji $\mathrm{F}$ ini menunjukan ada pengaruh secara simultan antara variabel bebas terhadap variabel terikat sehingga penelitian ini dapat dilanjutkan dengan uji t.

Tabel 7. Uji t

\begin{tabular}{ccccc}
\hline Variable & Coefficient & Std. Error & t-Statistic & Prob. \\
\hline $\mathbf{C}$ & 4.404856 & 0.072136 & 61.06300 & 0.0000 \\
CAR & 0.008300 & 0.003127 & 2.653863 & 0.0112 \\
NPF & -0.004612 & 0.002103 & -2.192920 & 0.0339 \\
\hline
\end{tabular}




\section{Sumber: Output Eviews 8}

thitung untuk kecukupan modal sebesar 2,653863 dengan arah hubungan positif dan nilai probabilitas (signifikansi) sebesar 0,0112 . Sedangkan $t_{\text {hitung }}$ untuk risiko kredit sebesar 2,192920 dengan arah hubungan negatif dan probabilitas (signifikansi) sebesar 0,0339. Untuk perhitungan $t_{\text {tabel }}$ didapatkan dengan cara menghitung signifikan level $0,05 \quad(\alpha=5 \%)$, jumlah sampel $\mathrm{N}=55$ dan jumlah variabel independen $\mathrm{K}=3$, maka $\mathrm{t}_{(0,05 /(\mathrm{K}-1) ;(55-\mathrm{K}))}=$ $\mathrm{t}_{(0,05 / 2 ; 52)}$ dilihat pada tabel uji $\mathrm{t}$ diperoleh nilai $t_{\text {tabel }}$ adalah sebesar 2,00665.

Sehingga untuk hipotesis yang pertama mengenai kecukupan modal (CAR) diketahui bahwa $t_{\text {hitung }}(2,653863)>t_{\text {tabel }}$ $(2,00665)$ dan nilai signifikansi $(0,0112)<$ 0,05 maka hal ini menunjukan bahwa $\mathrm{H}_{0}$ ditolak dan $\mathrm{H}_{\mathrm{a}}$ diterima yang artinya kecukupan modal (CAR) berpengaruh signifikan dengan terhadap likuiditas (FDR) dengan arah positif.

Sedangkan untuk hipotesis yang kedua mengenai risiko kredit (NPF) diketahui bahwa $t_{\text {hitung }}(2,192920)>t_{\text {tabel }}(2,00665)$ dan nilai signifikansi $(0,0339)<0,05$ maka hal ini menunjukan bahwa $\mathrm{H}_{0}$ ditolak dan $\mathrm{H}_{\mathrm{a}}$ diterima yang artinya risiko kredit (NPF) berpengaruh signifikan terhadap profitabilitas (ROA) dengan arah negatif.

\section{Pembahasan \\ Pengaruh Kecukupan Modal Terhadap Likuiditas}

Berdasarkan hasil uji $\mathrm{t}$ diperoleh nilai $t_{\text {hitung sebesar 2,653863 yang kemudian }}$ dibandingkan dengan nilai $\mathrm{t}_{\text {tabel }}$ distribusi $\mathrm{t}$ dengan derajat kebebasan $=55(\mathrm{n}-\mathrm{k})$ dan taraf signifikansi sebesar $5 \%$ atau 0,05 , sehingga diperoleh nilai $t_{\text {tabel }}$ sebesar 2,00665 sehingga $t_{\text {hitung }} \geq t_{\text {tabel }}$ atau sebesar $2,653863 \geq 2,00665$. Nilai Prob. kurang dari nilai signifikansi yaitu $0,0112 \leq 0,05$, maka $\mathrm{H}_{01}$ ditolak dan $\mathrm{H}_{\mathrm{a} 1}$ diterima. Hal ini dapat diartikan bahwa Kecukupan Modal berpengaruh terhadap Likuiditas. Nilai koefisien regresi Kecukupan Modal sebesar 0,008. Artinya jika Kecukupan Modal bertambah 1\%, maka Likuiditas akan mengalami peningkatan sebesar $0,008 \%$.

Hasil ini sesuai dengan teori yang dikemukakan oleh Buchory (2004) yang mengatakan bahwa semakin tinggi kecukupan modal maka likuiditas bank juga akan semakin tinggi karena fungsi intermediasi dapat dilaksanakan dengan optimal. Hasil penelitian ini juga didukung oleh beberapa penelitian terdahulu, yang dilakukan oleh Anindya (2016) dan Prihatiningsih (2011) yang hasilnya bahwa kecukupan modal berpengaruh positif dan signifikan terhadap likuiditas.

Penelitian ini tidak mendukung teori yang dikemukakan oleh Ali (2004) dan hasil penelitian yang dilakukan oleh Faisusza (2015) dan Rafikha (2013) yang dalam hasil penelitiannya bahwa kecukupan modal memiliki pengaruh negatif dan signifikan terhadap likuiditas.

Saat kecukupan modal mengalami kenaikan maka tingkat likuiditas juga mengalami kenaikan. Kenaikan tingkat kecukupan modal dikarenakan modal bank yang semakin meningkat dibandingkan dengan perubahan ATMR bank yang mengalami penurunan. Modal bank dapat meningkat dikarenakan sumber dana yang mengalami peningkatan dengan cara, melakukan laba ditahan, menambah modal disetor, dan bank juga meningkatkan jumlah saham, sedangkan ATMR bank berubah sesuai dengan ketentuan OJK yaitu bank diharuskan menurunkan tingkat ATMR. Dengan modal meningkat ditambah juga dengan DPK yang meningkat maka bank dapat lebih banyak menyalurkan pembiayaan, tetapi bank dianjurkan untuk menurunkan ATMR yang membuat bank menjadi lebih berhati-hati dalam menyalurkan pembiayaannya. Dana yang seharusnya disalurkan untuk pembiayaan disimpan menjadi kas oleh bank karena bank harus menurunkan kredit yang gagal bayar, dengan pembiayaan yang tidak maksimal maka FDR bank menjadi menurun dan likuiditas bank menjadi meningkat .

\section{Pengaruh Risiko Kredit Terhadap Likuiditas}

Berdasarkan hasil uji t diperoleh nilai thitung sebesar 2,192920 yang kemudian dibandingkan dengan nilai $t_{\text {tabel }}$ distribusi $t$ dengan derajat kebebasan $=55(\mathrm{n}-\mathrm{k})$ dan taraf signifikansi sebesar $5 \%$ atau 0,05, sehingga diperoleh nilai $t_{\text {tabel }}$ sebesar 2,00665 sehingga $t_{\text {hitung }} \geq t_{\text {tabel }}$ atau sebesar $2,192920 \geq 2,00665$. Nilai Prob. kurang dari nilai signifikansi yaitu $0,0339 \leq 0,05$, maka $\mathrm{H}_{01}$ ditolak dan $\mathrm{H}_{\mathrm{a} 1}$ diterima. Hal ini dapat diartikan bahwa Risiko Kredit berpengaruh terhadap Likuiditas. Nilai koefisien regresi Risiko Kredit sebesar 0,004. Artinya jika Risiko Kredit bertambah $1 \%$, maka Likuiditas akan mengalami peningkatan sebesar $0,004 \%$.

Hasil penelitian ini didukung oleh teori yang dikemukakan Leon dan Ericson (2007) yang mengatakan semakin kecil risiko kredit akan semakin baik tingkat kesehatan suatu bank karena minimnya 
kredit/pembiayaan yang gagal bayar, dimana gagal bayar pada suatu bank merupakan sinyal negatif bagi bank dan akan menurunkan tingkat likuiditas dan solvabilitas bank yang bersangkutan. Dan hasil ini didukung oleh penelitian yang dilakukan oleh Prihatiningsih (2011), Lina (2017), Enny (2016) dan Aulia (2016) yang mengatakan bahwa risiko kredit berpengaruh negatif dan signifikan terhadap likuiditas. Hal ini tidak sejalan dengan penelitian yang dilakukan oleh Anindya (2016) dan Muhammad Nafik (2015) yang mengatakkan bahwa hasil penelitiannya risiko kredit tidak berpengaruh terhadap likuiditas.

Semakin rendah tingkat risiko kredit bank maka tingkat likuiditas bank menjadi meningkat. Risiko kredit bank syariah merupakan rasio antara total pembiayaan yang bermasalah dengan total pembiayaan yang disalurkan. Risiko kredit yang menurun dikarenakan bank lebih berhatihati dalam menyalurkan dananya sehingga kualitas pendanaan yang disalurkan oleh bank semakin baik, karena dana yang disalurkan oleh bank hanya sedikit yang mengalami kredit macet, kredit diragukan dan kredit kurang lancar. Kegiatan bank dalam meminimalkan kredit macet membuat pembiayaan bank menjadi kurang maksimal karena bank lebih manjaga prinsip kehati-hatian, penurunan pembiayaan bank berdampak pada FDR bank yang menurun. Berdasarkan gambaran diatas maka likuiditas bank menjadi meningkat dan bank dapat dikatakan sehat dalam likuiditasnya.

\section{KESIMPULAN DAN SARAN}

Kesimpulan dalam penelitian ini yaitu Gambaran kecukupan modal pada Bank Umum Syariah yang diukur dengan indikator Capital Adequancy Ratio (CAR) selama periode 2012 - 2016 mengalami perkembangan fluktuatif cenderung meningkat.

Gambaran risiko kredit pada bank umum syariah yang diukur dengan indikator Non Performing Financing (NPF) selama periode 2012 - 2016 mengalami perkembangan yang terus meningkat pada setiap tahunnya.

Gambaran likuiditas pada bank umum syariah yang diukur dengan indikator Financing to Deposit Ratio (FDR) selama periode 2012 - 2015 mengalami penurunan tetapi pada tahun 2016 mengalami kenaikan.

Kecukupan modal berpengaruh positif terhadap likuiditas. Artinya setiap peningkatan kecukupan modal maka akan mempengaruhi peningkatan tingkat likuiditas, begitupula sebaliknya.

Risiko kredit berpengaruh negatif terhadap likuiditas. Artinya setiap peningkatan risiko kredit maka akan mempengaruhi penurunan tingkat likuiditas, begitupula sebaliknya.

Saran pada penelitian ini yaitu bagi bank umum syariah disarankan untuk memperhatikan tingkat kecukupan modal agar dapat menjaga tingkat likuiditas bank. Hal ini dapat dilakukan oleh bank dengan cara yang pertama yaitu melalui penawaran saham perdana kepada publik (initial public offering/IPO). Kedua, mengundang investor strategis \& mitra strategis baru, baik lokal maupun asing untuk menanamkan modalnya. Ketiga, bank melakukan penawaran umum terbatas dengan skema hak memesan efek terlebih dahulu (right issue) agar modal yang didapatkan oleh bank menjadi lebih meningkat. Keempat, dengan penambahan modal dari penyisihan laba dengan melakukan laba ditahan atau mengurangi dividen yang diberikan.

Bagi bank umum syariah disarankan untuk menurunkan risiko kredit agar dapat menjaga tingkat likuiditas bank. Hal ini dapat dilakukan oleh bank dengan cara lebih berhati-hati dalam pemberian pembiayaan dengan menganalisis debitur menggunakan prinsip $5 \mathrm{C}$ (Capital, Capability, Condition of Economy, Character, Collateral). Bank harus mengurangi penyaluran pembiayaan pada nasabah yang memiliki risiko kredit tinggi dan sebaliknya bank harus menambah penyaluran pembiayaan pada nasabah yang memiliki tingkat pengembalian yang baik.

Bagi bank umum syariah disarankan untuk menjaga tingkat likuiditas bank agar selalu menjadi bank yang selalu dipercayai oleh para nasabah untuk menyimpan dananya. Meningkatkan tingkat likuiditas dapat dilakukan dengan cara yang pertama, melakukan monitoring secara harian atas besarnya penarikan dana yang dilakukan oleh nasabah baik berupa penarikan melalui kliring maupun penarikan tunai. Kedua dengan melaksanakan monitoring secara harian atas semua dana masuk baik melalui incoming transfer maupun setoran tunai nasabah. Ketiga dengan menetapkan cadangan sekunder (secondary reserve) untuk menjaga posisi likuiditas Bank, antara lain menempatkan kelebihan dana ke dalam instrumen keuangan yang likuid seperti surat berharga pasar uang atau SBPU, sertifikat Bank Indonesia atau SBI dan surat berharga jangka pendek lainnya. 
Bagi penelitian selanjutnya, diharapkan dapat menambahkan indikator lain yang berpengaruh terhadap likuiditas bank selain kecukupan modal dan risiko kredit, menambahkan objek penelitian, menambahkan periode penelitian, serta menambahkan perbandingan antara likuiditas Bank Umum Syariah dengan likuiditas Bank Umum Konvensional.

\section{DAFTAR PUSTAKA}

Adiwarman A Karim. 2011. Bank Islam Analilsis Fiqih dan Keuangan, edisi 4. Jakarta : PT. Rajawali Pers.

Akhtar, Ali, Sadaqat, 2011. Liquidity Risk Management: A comparative study between Conventional and Islamic Banks of Pakistan. Vol. 1, Issue.

Ali, Masyhud, (2006), Manajemen Risiko, Strategi Perbankan Dan Dunia Usaha Menghadapi Tantangan Globalisasi Bisnis, PT. Raja Grafindo Persada, Jakarta

Ali, Mashud. 2004. Asset Liability Management : Menyiasati Risiko Pasar dan Risiko Operasional. Jakarta : PT. Gramedia

Alma, Buchori. (2004). Manajemen Pemasaran dan Pemasaran Jasa. Bandung: Alfabeta.

Anindya Ardiansari. (2016). Pengaruh Dana Pihak Ketiga, Non Performing Financing, Capital Adequancy Ratio, Return on Asset terhadap tingkat Likuiditas. Management Analysis Journal. Semarang.

Arikunto, S. (2010). Prosedur Penelitian Suatu Pendekatan Praktik. Jakarta: Rineka Cipta.

Aulia Nazala Ramadhani. (2016). Pengaruh variabel size, Capital Adequacy Ratio (CAR), Return On Assets (ROA), Non Performing Loan (NPL), dan inflasi terhadap Loan to Deposit Ratio (LDR) pada Bank Umum Konvensional yang terdaftar di Bursa Efek Indonesia (BEI) periode 2010-2014. Skripsi pada Program Sarjana Fakultas Ekonomika dan Bisnis Universitas Diponegoro: yang ditebitkan.

Berger, Allen N. \& DeYoung, Robert, 2006. "Technological Progress and the Geographic Expansion of the Banking Industry," Journal of Money, Credit and Banking, Blackwell Publishing, vol. 38(6), pages 1483-1513, September.

Boy Leon \& Sonny Ericson. 2007. Manajemen aktiva pasiva bank non devisa. Jakarta: Grasindo.
Dendawijaya, Lukman, 2009, Manajemen Perbankan, Jakarta: Ghalia Indonesia.

Enny Susilowati. (2016). Pengaruh Dana Pihak Ketiga (DPK), Capital Adequancy Ratio (CAR), dan Non Performing Financing (NPF) Terhadap Likuiditas Perbankan Syariah di Indonesia Periode 20112015. Skripsi fakultas Ekonomi dan Bisnis Universitas Islam Negeri Syarif Hidayatullah : Jakarta

Faisusza Bani dan Rizal Yaya. (2015). Faktor-faktor yang Mempengaruhi Risiko Likuiditas pada Perbankan Konvensional dan Syariah di Indonesia. Jurnal International Conference of Accounting and Finance Universitas Muhammadiyah Yogyakarta : Yogyakarta

Ismal, Rifki. 2011. The Indonesian Islamic Banking Theory and Practices. Gramata Publishing.

Kasmir. 2014. Analisis Laporan Keuangan. Edisi Satu. Cetakan Ketujuh. Jakarta : PT Raja Grafindo Persada.

Khaerul Umam. 2013. Manajemen Perbankan Syariah. Bandung: CV Pustaka Setia

Lina Nugraha Rani. (2017). Analisis Pengaruh Faktor Eksternal dan Internal Perbankan Terhadap Likuiditas Perbankan Syariah di Indonesia Periode Januari 2003 Oktober 2015. Jurnal Ekonomi Syariah Fakultas Ekonomi dan Bisnis Universitas Airlangga : Surabaya

Muhammad Nafik H R. (2015). Faktorfaktor yang Berpengaruh terhadap Likuiditas Bank Syariah. Jurnal Ekonomi Syariah Teori dan Terapan Fakultas Ekonomi dan Bisnis Universitas Airlangga : Surabaya

Muharam, Harjum. The Influence of Fundamental Factors to Liquidity Risk on Banking Industry: Comparative Study between Islamic Bank and Conventional Bank in Indonesia (October 12, 2013). Conference In Business, Accounting And Management (Cbam) 20121 (2), 359-368, UNISSULA, SEMARANG INDONESIA.

Mulyono, Teguh Pudjo, Manajemen Perkreditan Bagi Bank Komersil, 
BPFE Yogyakarta, Yogyakarta, 1996

Munawir S. (2002). Analisis Laporan Keuangan. Yogyakarta: Liberty

Prihatiningsih, S.E (2011). Pengaruh Dana Pihak Ketiga, Capital Adequacy Ratio, Imbal Hasil Sertifikat Bank Indonesia Syariah (SBIS), Imbal Hasil Sertifikat Investasi Mudharabah Antarbank Syariah (SIMA), dan Non Performing Financing (NPF) terhadap Financing to Deposit Ratio (FDR) pada Bank Umum Syariah (BUS).

Rafikha Rustianah Mustafidan. (2013). Faktor-faktor yang Mempengaruhi Likuiditas pada Bank Umum Syariah di Indonesia Periode 20072012. Skripsi Fakultas Syariah dan Hukum Universitas Islam Negeri Sunan Kalijaga : Yogyakarta

Rivai. Veithzal. 2012. Credit Management Handbook: Teori, Konsep, dan Aplikasi Panduan Praktis Mahasiswa, Bankir dan Nasabah. Jakarta: Raja Grafindo Persada.

Siti Rahmi Nur Utami. Pengaruh Dana Pihak Ketiga (DPK), Sertifikat Bank Indonesia Syariah (SBIS), Rasio Kecukupan Modal (CAR), dan Non Performing Financing (NPF) terhadap Financing to Deposit Ratio pada bank Umum Syariah di Indonesia. 